\title{
SELF-COMPACTING MORTAR PRODUCTION BY USING CALCIUM ALUMINATE CEMENT
}

Gizem TÜREDİ, Civil Engineering Department, Muğla Sıtkı Koçman University, Turkey, turedigizem@gmail.com

(iD) https://orcid.org/0000-0001-5090-1163)

Özlem KASAP KESKIN*, Civil Engineering Department, Muğla Sıtkı Koçman University, Turkey, okasapkeskin@mu.edu.tr

(iD https://orcid.org/0000-0003-4475-2186)

Süleyman Bahadır KESKIN, Civil Engineering Department, Muğla Sıtkı Koçman University, Turkey, sbkeskin@mu.edu.tr (iD) https://orcid.org/0000-0002-2802-5379)

Received: 07-02-2020, Accepted: 12-07-2020

*Corresponding author

Research Article

DOI: $10.22531 /$ muglajsci.686144

\begin{abstract}
The aim of this study is to produce self-compacting mortar with calcium aluminate cement. The advantages of selfcompacting mortars like filling and passing ability without the need of vibration process and the superior properties of calcium aluminate cement like abrasion resistance, high thermal resistance, high acid resistance, and high early strength are intended to be combined. However, hydration process of calcium aluminate cement might cause strength reduction at later ages. Therefore, in order to prevent the possibility of strength reduction, several supplementary binders such as gypsum, fly ash, ground granulated blast furnace slag and silica fume were utilized in the mortar mixtures. In this sense, 11 different self-compacting mortars were produced, and those mortars were tested to obtain values of mini slump flow, setting time, abrasion resistance and 1,2, 7, 28, and 90 day flexural and compressive strength. Test results showed that different supplementary binders exhibited different behaviors in mortar mixtures. As a conclusion, it was seen that the production of self-compacting mortar with calcium aluminate cement was possible.
\end{abstract}

Keywords: Calcium Aluminate Cement, Self-compacting Mortar, Mortar Production

\section{KALSIYYUM ALÜMINATLI ÇIMENTO KULLANIMI İLE KENDİLİĞİNDEN YERLEŞEN HARÇ ÜRETIMI}

\section{Özet}

Bu çalışmanın amacı, kalsiyum alüminatlı çimento ile kendiliğinden yerleșen harç üretmektir. Kendiliğinden yerleșen harçların vibrasyon işlemine ihtiyaç duymadan doldurma ve geçme kabiliyeti gibi avantajları ile kalsiyum alüminatlı çimentoların aşınma direnci, yüksek ısıl dayanıklılık, yüksek asit direnci, yüksek erken dayanım gibi üstün özelliklerinin birleștirilmesi amaçlanmaktadır. Bununla birlikte, kalsiyum alüminatlı çimentoların hidratasyonu ileriki yaşlarda dayanım kayıplarına yol açabilmektedir. Bu sebeple, dayanım kaybı ihtimalini önlemek amacıyla, alçı, uçucu kül, öğütülmüş granüle yüksek firın cürufu, silis dumanı gibi ilave bağlayıcı malzemelerden harç karışımlarında yararlanılmıştır. Bu bağlamda, 11 farklı kendiliğinden yerleşen harç üretilmiştir ve bu harçların yayılma, priz süresi, aşınma dirençleri ve 1, 2, 7, 28 ve 90 günlük eğilme ve basınç dayanımları belirlenmiştir. Test sonuçları ilave bağlayıcıların harç karışımlarında farklı davranışlar sergilediğini göstermiştir. Sonuç olarak, kalsiyum alüminatlı çimento ile kendiliğinden yerleșen harç üretiminin mümkün olduğu görülmüştür.

Anahtar Kelimeler: Kalsiyum Alüminatlı Çimento, Kendiliğinden Yerleşen Harç

Cite

Türedi, G., Kasap Keskin, Ö., Keskin, S.B., (2020). "Self-compacting Mortar Production by Using Calcium Aluminate Cement", Mugla Journal of Science and Technology, 6(2), 18-27.

\section{Introduction}

Over the decades, self-compacting mortar (SCM) has been noticed by researchers as a new development product from different approaches in the manner of flowability, high viscosity, segregation resistance, longevity, high stability, reducing manpower and consolidating capacity under its own weight as easier placing without vibration (1). Furthermore, that type of mortar can be employed in usages like grouting, filling narrow places, and repair works in construction departments (2). On the other hand, calcium aluminate cement (CAC), type of non-portland cement, satisfies the expectations of various requirements such as early strength gaining, resistance to wide range of chemical attacks, rapid hardening, resistance to high temperature, and abrasion endurance $(3,4)$. Besides, it has also used for several application fields which can be summarized as refractory castables, rapid set purposes like repair mortars, tile adhesives, rehabilitation 
process, and water stopping products (5). However, even if both SCM and CAC have various advantages, they also have remarkable disadvantages. In detail, high volume percentage for cement usage in SCM production is necessary under the conception of raw material requirement but, obviously, this is not economical in many ways. Moreover, according to discipline of flowability and self-consolidating property, need of superplasticizer usage also causes cost increase. In other respects, because of CAC's production cost, the yearly manufacturing of that type of cement is significantly less than ordinary portland cement (OPC). Therefore, economical solutions are nearly as important as mechanical properties in the scope of preferability (6, 7).

Another issue is hydration process of CAC which is different from OPC in the manner of conversion reaction products. However, that situation may cause strength reduction at later ages. Antonovic et al. (8), investigated that temperature changes had clear effects on the formation process and products of hydrated CAC structure at elevated temperatures starting from $5^{\circ} \mathrm{C}$ up to more than $1000^{\circ} \mathrm{C}$ with the occurrence of several types of hydrates and crystals according to temperature degree.

Based on previous researches and applications, it can be said that supplementary cementitious binder usage is a satisfactory solution to reduce high cost of that kind of mortar (9). Generally, in literature, portland cement (PC), limestone, fly ash, ground granulated blast furnace slag (GGBFS), silica fume and gypsum are incorporated with CAC as a binder (9-18).

Earlier studies presented that the addition of fly ash and gypsum in CAC systems could change the hydration mechanisms and there was an inclination for growth of ettringite ratio with these supplementary binder substitution $(9,10,17)$. Additionally, both fly ash and limestone fillers in SCM positively affected the initial viscosity whereas limestone fillers affected the compressive strength in the manner of early strength gain more than fly ash in SCM production (18). Another study also demonstrated that limestone addition to CAC-calcium sulfate systems improved marginally the hydration mechanism of CAC by the formation of hemicarboaluminate (HC) and monocarboaluminate (CA) compositions (15). Based on the study conducted by Lopez et al. (11), microstructure of cement pastes could be influenced by the addition of silica fume and fly ash. This situation was also observed by scanning electron microscopy (SEM) and near-infrared (NIR) spectroscopy. It was said that gehlenite might be formed in silica fume grains. Likewise, silica fume addition to CAC had influences on setting time like shorter working time limit and flowability of castable systems like low consolidating capacity (12). A study including comprehensive examination about the alkaline activation of GGBFS showed that there was a direct relationship among the absence of GGBFS and compressive strength (13). Moreover, another investigation performed by Kurca et al. indicated the addition of GGBFS to CAC systems was considerably effective on compressive strength development in a positive way according to ultimate replacement ratio, where GGBFS ratio was more than $40 \%$ particularly (14). Kirca (14) carried out CAC-PC binary systems and it resulted in the fact that there was no extreme difference between pure CAC and CAC-PC mixes within the context of serious strength changes and amount of formation products of CAC conversion reactions.

Although there are many studies related to selfcompacting mortars and self-compacting concretes in the literature, production of SCM with CAC can be a new area of interest for increasing the utilization of CAC in the construction industry. The combination of the advantages of CAC and SCM is expected to serve as a basis for a production of an effective repair material. In this study, 11 different SCM mixtures were produced after many trials for the type and dosage of superplasticizer, water/cement ratio, sand/cement ratio and supplementary material/binder ratio. Besides the mini slump flow diameter and setting time, hardened state properties such as flexural and compressive strength and abrasion resistance were also determined for all SCM mixtures produced within the scope this study.

\section{Experimental Program}

The experimental study contained two parts which were conducted according to fresh and hardened states. Fresh state tests consisted of mini slump flow and setting time while hardened state tests included 1, 2, 7, 28, and 90 day flexural and compressive strength and abrasion resistance tests. On purpose of those stages, 11 different mortar samples were produced, out of which one was control mixture with same water/binder $(\mathrm{w} / \mathrm{b})$ and binder/aggregate $(\mathrm{b} / \mathrm{a})$ ratios.

\subsection{Materials}

Calcium aluminate cement (CAC, obtained from ÇimSA Cement Production and Trade Cooperation in Mersin) was blended with supplementary binders which were itemized as gypsum, silica fume (from Eti Metallurgy Antalya Ferrochrome Plant), Class F fly ash (from Yatağan Thermal Power Plant) and GGBFS (from İskenderun Iron and Steel Plant).

The chemical compositions and some physical and mechanical features of the supplementary binders (attained by manufacturers or determined in Materials of Construction Laboratory of Muğla Sitkı Koçman University) were shown in Table 1 and 2. Additionally, particle size distributions of binders were also examined in Fig.1. 
Table 1. Chemical and physical properties of binders

\begin{tabular}{|c|c|c|c|c|c|}
\hline & $\mathrm{CAC}$ & Silica Fume & GGBFS & Gypsum & Fly Ash \\
\hline \multicolumn{6}{|l|}{ Chemical Analysis (\%) } \\
\hline $\mathrm{CaO}$ & 35.36 & 0.62 & 34.48 & 32.27 & 11.21 \\
\hline $\mathrm{SiO}_{2}$ & 4.23 & 91.96 & 38.40 & 0.39 & 50.04 \\
\hline $\mathrm{Al}_{2} \mathrm{O}_{3}$ & 40.71 & 1.20 & 10.96 & 0.01 & 22.85 \\
\hline $\mathrm{MgO}$ & 0.81 & 1.02 & 7.14 & 1.10 & 2.23 \\
\hline $\mathrm{SO}_{3}$ & 0.03 & 0.12 & 1.48 & 42.94 & 0.78 \\
\hline $\mathrm{K}_{2} \mathrm{O}$ & 0.12 & 1.16 & 0.86 & 0.05 & 2.50 \\
\hline $\mathrm{Na}_{2} \mathrm{O}$ & 0.13 & 0.67 & 0.18 & 0.02 & 0.27 \\
\hline $\mathrm{Fe}_{2} \mathrm{O}_{3}$ & 16.52 & 0.84 & 0.81 & 0.02 & 8.02 \\
\hline \multicolumn{6}{|l|}{ Physical Properties } \\
\hline Blaine Fineness $\left(\mathrm{cm}^{2} / \mathrm{g}\right)$ & 3500 & - & 4250 & - & 2850 \\
\hline Specific Gravity $\left(\mathrm{g} / \mathrm{cm}^{3}\right)$ & 3.24 & 2.20 & 2.79 & 2.46 & 2.28 \\
\hline Final Setting Time (Min.) & 260 & - & - & - & - \\
\hline
\end{tabular}

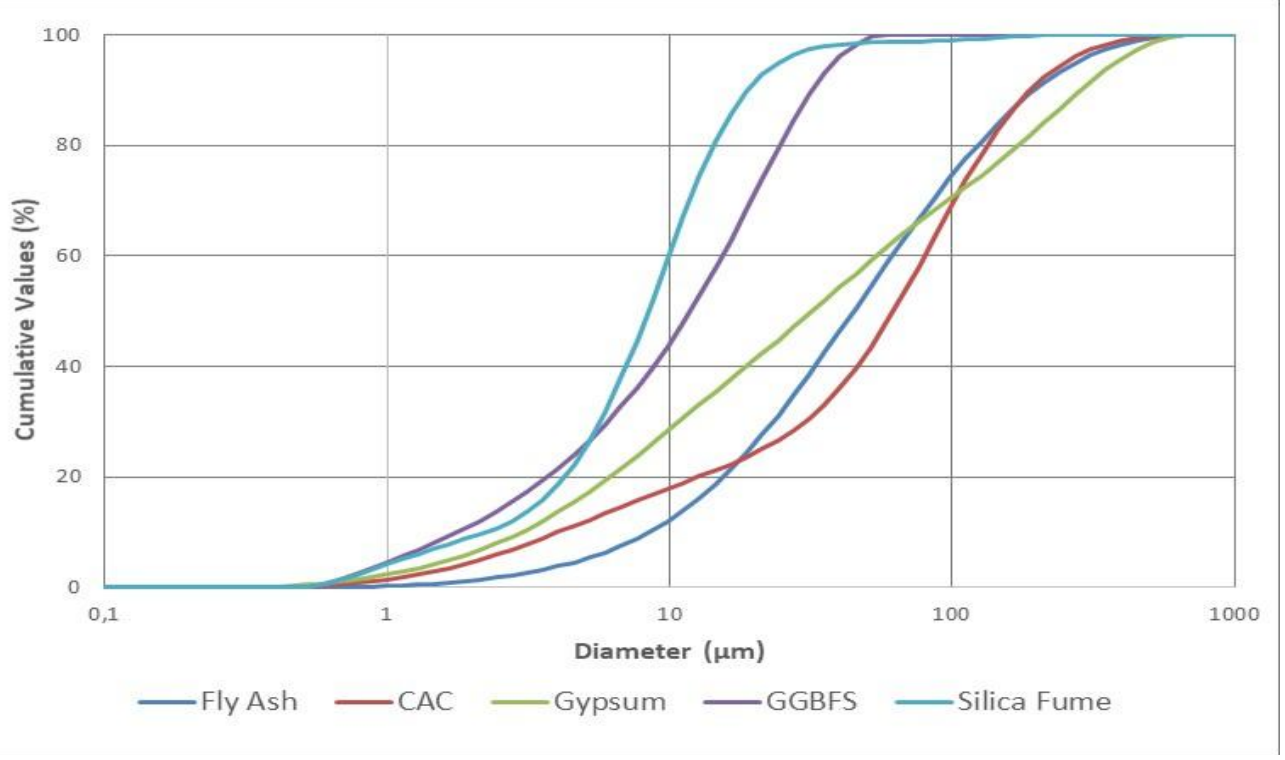

Figure 1. Particle size distribution of binders

On the other hand, silica sand was used as an aggregate and the specific gravity of the aforementioned sand was obtained as 2.54. Besides, Muğla city municipal tap water was used as the mixing water for all samples.

Table 2. Mechanical properties of CAC

\begin{tabular}{ll}
\hline \multicolumn{2}{l}{ Compressive Strength (MPa) at } \\
6h & \\
$24 \mathrm{~h}$ & 39.1 \\
Flexural Strength $(\mathrm{MPa})$ at & 74.0 \\
$6 \mathrm{~h}$ & \\
$24 \mathrm{~h}$ & 5.0 \\
\hline
\end{tabular}

Additionally, under the light of compatibility and flowability, superplasticizer selection and usage are important to produce self-consolidating mortar (19). Therefore, based on trial and error tests, a polycarboxylate ether type superplasticizer was chosen to be employed in all mixtures with different percentages aiming the minimum slump flow diameter as $24 \mathrm{~cm}$ (20).

\subsection{Mixtures and Methods}

Within the circumstances of maximum flowability and minimum segregation principles which were aimed for this study, $w / b$ and $b / a$ ratios were determined by trying several different mixtures of pure CAC mortars as 0.5 and 0.6 , respectively. Then, mixtures composed of different supplementary binders including PC at different ratios together with CAC were produced 
depending on the literature and many trial and error tests. However, because of PC's incompatibility with CAC, CAC-PC system was not taken into considerations SCM production in this study. Afterwards, 10 different CAC based self-compacting mortar systems (except control sample) were conducted with 5 different binders which are CAC, GGBFS, gypsum, fly ash, and silica fume to observe how the reactions of those supplementary binders gave results according to amounts in mixtures in short and long term by required fresh and hardened tests, because, binder selection has an important effect on strength, viscosity, and consistency (21).
Combinations naming, proportions, and volume fractions of mixtures were shown in Tables 3 and 4 . In the labeling of the mixtures, the letter designates the supplementary binder and the number designates the replacement percentage of supplementary binder with CAC by weight. In Tables 3 and $4, C$ refers to control mixture, G, F, SF and S refer to gypsum, fly ash, silica fume and GGBFS, respectively.

Table 3. CAC based combinations

\begin{tabular}{ccccccc}
\hline Mixtures & \multicolumn{5}{c}{ Binder Replacement (\%) } & Superplasticizer (\% Binder Mass) \\
\hline & CAC & Gypsum & Fly Ash & Silica Fume & GGBFS & \\
\hline C & 100 & - & - & - & - & 0.32 \\
G2 & 98 & 2 & - & - & - & 0.31 \\
G4 & 96 & 4 & - & - & - & 0.25 \\
G8 & 92 & 8 & - & - & - & 0.70 \\
F20 & 80 & - & 20 & - & - & 0.32 \\
SF5 & 95 & - & - & 5 & - & 0.79 \\
SF10 & 90 & - & - & 10 & - & 1.11 \\
S20 & 80 & - & - & - & 20 & 0.95 \\
S40 & 60 & - & - & - & 40 & 0.32 \\
S60 & 40 & - & - & - & 60 & 0.35 \\
S80 & 20 & - & - & - & 80 & 0.29 \\
\hline
\end{tabular}

Table 4. The amounts of ingredients in SCM mixtures

\begin{tabular}{cccccccc}
\hline Mixtures & \multicolumn{7}{c}{$\left(\mathrm{kg} / \mathrm{m}^{3}\right)$} \\
\hline & CAC & Gypsum & Fly Ash & Silica Fume & GGBFS & Silica Sand & Water \\
\hline C & 682 & - & - & - & - & 1138 & 341 \\
G2 & 668 & 14 & - & - & - & 1138 & 341 \\
G4 & 654 & 28 & - & - & - & 1138 & 341 \\
G8 & 628 & 54 & - & - & - & 1138 & 341 \\
F20 & 546 & - & 136 & - & - & 1138 & 341 \\
SF5 & 648 & - & - & 34 & - & 1138 & 341 \\
SF10 & 614 & - & - & 68 & - & 1138 & 341 \\
S20 & 546 & - & - & - & 136 & 1138 & 341 \\
S40 & 410 & - & - & - & 272 & 1138 & 341 \\
S60 & 274 & - & - & - & 408 & 1138 & 341 \\
S80 & 136 & - & - & - & 546 & 1138 & 341 \\
\hline
\end{tabular}




\subsection{Experiments}

According to the conception of self-compacting mortar production with CAC, applied tests can be categorized in two groups as fresh and hardened state tests. Türedi (2019) provides the details of all the tests applied to produce SCM mixtures and to determine their properties (22).

Firstly, for fresh state, mini slump flow test was performed to observe flowability and compactibility without any segregation and bleeding with using certain amount of supplementary binders and superplasticizer by average slump flow diameter calculation (23).

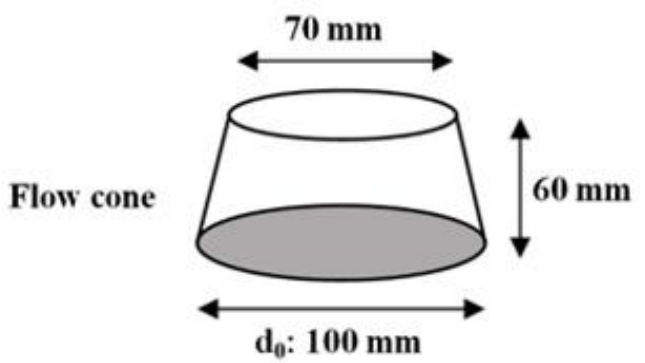

Figure 2. Mini-slump flow cone dimensions (19)

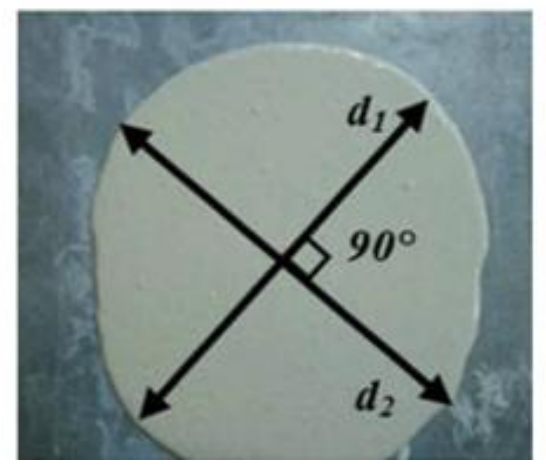

Figure 3. Two dimensions in two vertical directions

In pursuant to ASTM C143 (24), slump flow diameter was determined by using the mini slump of which dimensions were provided in Fig. 2 (19) as the average of two diameters measured after the flow completed (Fig. 3). The target limit for slump flow diameter was chosen in the range of $24 \mathrm{~cm}$ to $30 \mathrm{~cm}$ according to EFNARC (25) limit in this study.

Secondly, as another fresh state property, the setting time of mortar mixtures was recorded according to ASTM C807-13 (26) by modified Vicat apparatus which was created by plunger and needle for mortars to obtain final setting time in accordance with visual inspection (27).

On the other hand, for hardened state of mortars, abrasion resistance test was applied according to ASTM C944-99 (28) by abrasion device which was shown in Fig. 4. Then, thickness measurements at 3 different points taken by every 2 out of six minutes were recorded to find average depth for abrasion resistance of mortar samples. In that purpose, $15-\mathrm{cm}$ cubic mortar specimens were used. The abrasion resistance of mortar specimens was determined at five different ages such as $1,2,7,28$ and 90 days. The target of test was also to observe the capacity of mortar mixtures to be used as a repair mortar for the cases in which abrasion was important such as highways.

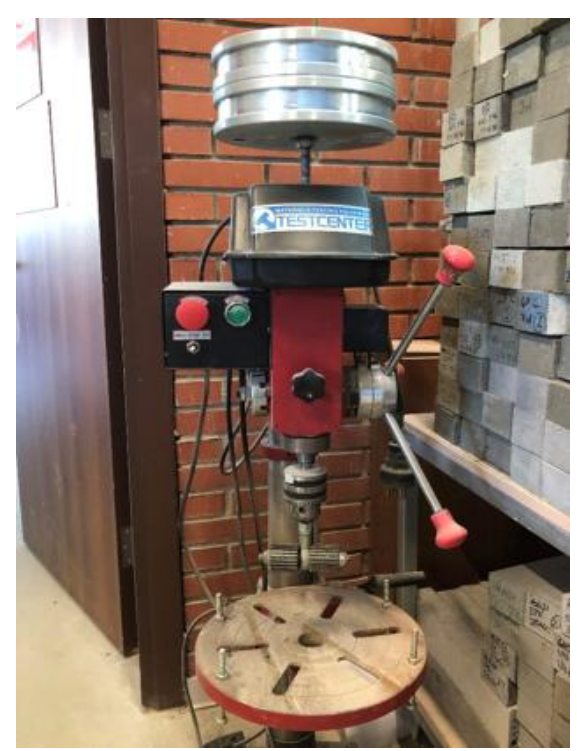

Figure 4. Abrasion device

In the manner of flexural and compressive strength tests, $4 \times 4 \times 16-\mathrm{cm}$ prismatic specimens were used for five different ages according to TS EN 196-1:2016 (29). Three-point bending test was applied on three specimens at each test age, and the average of three results were recorded as the flexural strength. Later on, the broken pieces were used to determine the compressive strength as the average of six test results.

\section{Test Results and Discussion}

\subsection{Fresh State Results}

The results of mini slump flow and setting time tests were illustrated in Table 5. Slump flow diameters were kept in the range of $24-30 \mathrm{~cm}$ by adjusting the superplasticizer content. While determining the amount of superplasticizer in the mixtures, no observation of visual bleeding and segregation was aimed. The final flow appearances obtained after the mini slump flow test for all mixtures were shown in Fig.5.

Comparison of mini slump flow diameters (Table 5) and superplasticizer contents (Table 3) yielded that the flow behavior was not only affected by the superplasticizer content but also by the type and amount of binding material. The presence of silica fume increased the superplasticizer requirement significantly. However, the increment of silica fume amount decreased slump flow diameter because of fine grained structure of silica fume (30). On the other hand, ground granulated blast furnace slag replacement at high amounts did not create a clear difference in the flow characteristics. 20\% replacement of CAC with fly ash result in similar slump 
flow diameter with the same superplasticizer content as the control mixture. Finally, it was seen that the increase in the replacement amount of gypsum led to an increase in the superplasticizer requirement.

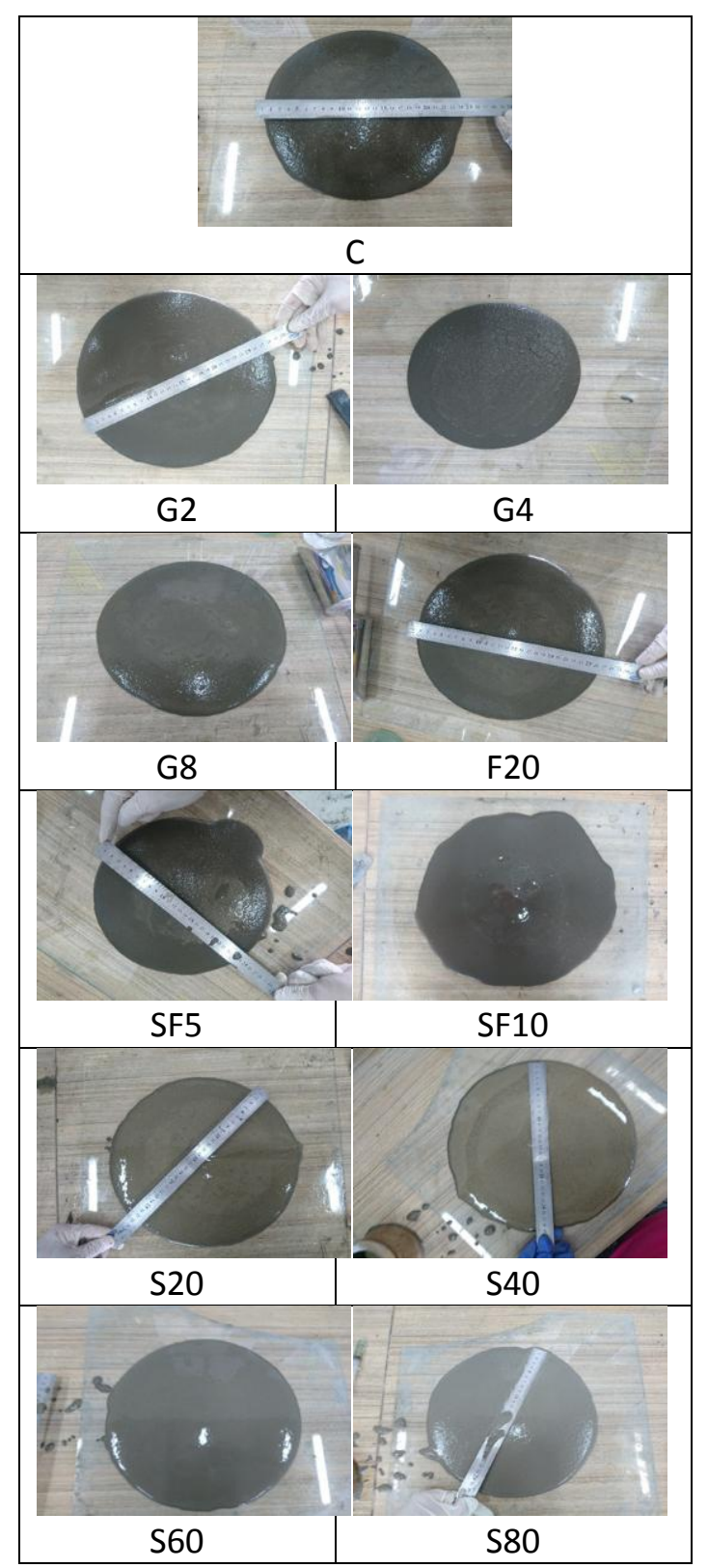

Figure 5. Images obtained by mini slump flow
Table 5. Fresh state test results of mortars

\begin{tabular}{cccc}
\hline Mixtures & $\begin{array}{c}\text { Slump } \\
\text { flow } \\
\text { diameter } \\
(\mathrm{cm})\end{array}$ & $\begin{array}{c}\text { Final } \\
\text { setting } \\
\text { time } \\
(\mathrm{min})\end{array}$ & $\begin{array}{c}\text { Superplasticizer } \\
\text { content } \%)\end{array}$ \\
\hline C & 24.0 & 255 & 0.32 \\
G2 & 27.0 & 180 & 0.31 \\
G4 & 25.0 & 150 & 0.25 \\
G8 & 29.0 & 120 & 0.70 \\
F20 & 26.0 & 240 & 0.32 \\
SF5 & 28.0 & 270 & 0.79 \\
SF10 & 24.5 & 195 & 1.11 \\
S20 & 28.0 & 405 & 0.95 \\
S40 & 29.0 & 315 & 0.32 \\
S60 & 29.0 & 390 & 0.35 \\
S80 & 27.0 & 360 & 0.29 \\
\hline
\end{tabular}

As seen from Table 5, type and replacement ratio of supplementary binders also affected the final setting time of CAC containing SCM mixtures. Presence of gypsum accelerated the setting of mortars such that the higher the amount of gypsum, the shorter the setting time. According to previous research conducted by Kirca (31), gypsum addition accelerated setting time due the occurrence of ettringite formation. On the other hand, replacement with GGBFS led to a significant retardation in the setting process of SCM mixtures as compared to control mixture. Under the circumstances of silica fume addition to CAC, the effect on setting time varied depending on the amount of silica fume in mortar mixtures.

As shown in Table 5, even five percentage increment of silica fume ratio was quite effective on final setting time such that an increase in the silica fume amount from 5 to $10 \%$ in mortars reduced the setting time from 270 to 195 minutes. When fly ash replacement was evaluated, there was not a significant difference between setting time of F20 and control mixture, C. Additionally, the superplasticizer contents and slump flow diameters were also similar. Replacement of CAC by $20 \%$ of fly ash in SCM production did not alter the fresh state properties in this study. On the other hand, research studied by Güneyisi and Gesoğlu (32) showed that fly ash addition contributed fresh state properties comparing to control mixture. As a result, as long as the superplasticizer type and content were adjusted properly, it was possible to produce SCM mixtures with satisfactory fresh properties by using CAC.

\subsection{Hardened State Results}

Hardened state properties of SCM mixtures produced by CAC were also determined. For this purpose, abrasion resistance, flexural strength and compressive strength 
of each SCM mixtures were obtained at several different ages.

Abrasion resistance test results for the five different ages of 1, 2, 7, 28 and 90 days were shown in Table 6 as the decrease in thickness of $15 \mathrm{~cm}$ cubic specimens. The decrements in the thickness generally smaller than 2.0 $\mathrm{mm}$ for all mixtures except S80 at all test ages. S80 mixture was so weak under the action of abrasion that it was not possible to apply the test at all ages. Additionally, the reduction in thickness for S60 mixture was also slightly higher as compared to other SCM mixtures. Therefore, it could be concluded that GGBFS replacement in high ratios was not recommended in abrasion resistance point of view.

Furthermore, at 90 days, all mixtures except G2, S60 and S80 showed similar or better performance against resistance than the control mixture. In literature, using fly ash and silica fume in self-compacting concrete improved hardened properties to abrasion resistance (33). When the results were taken into considerations under the light of gypsum, fly ash and silica fume addition to CAC in SCM, there were no considerable differences in test results. Nevertheless, the abrasion test results were small and similar to each other for SCM mixtures produced by different supplementary binders other than SCM mixtures containing high amounts of GGBFS, respectively.

The main issue about the CAC mortars and concretes is the possible strength reduction in time due to phase transformation [8]. Therefore, SCM mixtures containing different supplementary binders together with CAC were produced in this study. Strength development behavior for 90 days were observed for each mixture. The flexural and compressive strength test results of mortar mixtures were shown in Tables 7 and 8 .

Table 6. Abrasion resistance test results

\begin{tabular}{cccccc}
\hline Mixtures & \multicolumn{5}{c}{ Change in thickness (mm) } \\
\hline & 1 Day & 2 Days & 7 Days & 28 Days & 90 Days \\
\hline C & 0.25 & 0.44 & 0.61 & 0.69 & 0.41 \\
G2 & 0.50 & 1.12 & 0.78 & 0.32 & 1.63 \\
G4 & 0.81 & 1.21 & 0.71 & 0.27 & 0.36 \\
G8 & 0.79 & 0.75 & 0.66 & 0.24 & 0.32 \\
F20 & 1.98 & 0.63 & 0.71 & 0.22 & 0.31 \\
SF5 & 0.95 & 1.40 & 0.61 & 0.25 & 0.21 \\
SF10 & 0.72 & 0.67 & 0.65 & 0.18 & 0.23 \\
S20 & 0.08 & 0.28 & 0.23 & 0.01 & 0.31 \\
S40 & 0.02 & 0.33 & 0.21 & 0.60 & 0.48 \\
S60 & 1.35 & 0.45 & 1.90 & 2.06 & 1.00 \\
S80 & 5.41 & 49.5 & - & - & - \\
\hline
\end{tabular}

Table 7. Flexural strength test results

\begin{tabular}{cccccc}
\hline Mixtures & \multicolumn{5}{c}{ Flexural strength (MPa) } \\
\hline & 1 Day & 2 Days & 7 Days & 28 Days & 90 Days \\
\hline C & 5.15 & 8.03 & 7.17 & 9.43 & 10.60 \\
G2 & 4.47 & 6.55 & 6.02 & 5.41 & 6.12 \\
G4 & 3.62 & 6.13 & 5.27 & 5.54 & 6.53 \\
G8 & 3.32 & 4.77 & 3.04 & 4.38 & 5.82 \\
F20 & 4.13 & 6.44 & 4.86 & 5.96 & 6.50 \\
SF5 & 4.87 & 5.73 & 7.75 & 5.01 & 8.10 \\
SF10 & 5.37 & 6.74 & 7.53 & 7.80 & 10.28 \\
S20 & 6.55 & 6.77 & 7.16 & 8.71 & 8.72 \\
S40 & 4.71 & 5.36 & 6.33 & 6.31 & 7.25 \\
S60 & 2.48 & 2.84 & 2.87 & 4.19 & 4.93 \\
S80 & 2.55 & 1.53 & 1.66 & 4.32 & 3.94 \\
\hline
\end{tabular}


Table 8. Compressive strength test results

\begin{tabular}{cccccc}
\hline Mixtures & \multicolumn{5}{c}{ Compressive strength (MPa) } \\
\hline & 1 Day & 2 Days & 7 Days & 28 Days & 90 Days \\
\hline C & 47.02 & 47.17 & 56.54 & 62.34 & 49.76 \\
G2 & 28.72 & 24.42 & 27.04 & 32.70 & 22.00 \\
G4 & 25.61 & 24.71 & 28.41 & 29.43 & 22.00 \\
G8 & 15.98 & 16.63 & 19.03 & 22.16 & 19.00 \\
F20 & 28.07 & 31.53 & 35.24 & 37.11 & 32.82 \\
SF5 & 33.39 & 35.28 & 36.40 & 42.68 & 53.10 \\
SF10 & 40.35 & 44.43 & 46.83 & 55.45 & 56.00 \\
S20 & 29.39 & 39.94 & 50.46 & 55.18 & 46.95 \\
S40 & 20.03 & 28.31 & 35.40 & 35.56 & 39.47 \\
S60 & 9.82 & 11.96 & 14.01 & 17.21 & 14.38 \\
S80 & 2.47 & 13.43 & 16.71 & 16.56 & 3.11 \\
\hline
\end{tabular}

In case of flexural strength results (Table 7), significant reduction in strength did not observed; the general trend was to increase slightly with time. Replacement of CAC with supplementary binders decreased the flexural strength capacity of SCM mixtures, especially at later ages. After the control mixture, the highest flexural strength results were obtained for SF10 mixtures. SF5 and S20 mixtures also had high flexural strength values as compared to other mortar mixtures. On the other hand, high replacement ratios with GGBFS caused a huge amount of reduction in flexural strength capacity of SCM mixtures. Presence of gypsum and fly ash showed similar effect on the flexural strength results.

In terms of compressive strength test (Table 8), strength reduction at later ages $(90$ days $)$ were observed in several mixtures. Although the compressive strength values of all mixtures gradually increased for the first 28 days, the strength loss was observed in other mixtures except SF5, SF10 and S40 at 90 days. The compressive strength of control mixture was reduced by $20 \%$ at 90 days with respect to 28 -day result. This situation can be explained by the conversion reactions of CAC as stated in the literature $(34,35)$. However, as seen by the test results, this strength loss was prevented by the presence of silica fume and GGBFS, especially at low ratios. However, higher contents of GGBFS in CAC containing SCM mixtures affected the hardened state properties adversely.

When the early compressive strength values (first 28 days) of the mixtures were compared, it was seen that replacement of CAC with supplementary binders caused decrement regardless the type and amount of binder. In CAC-gypsum combination, the reduction was in opposite relation with the replacement ratio at all ages. For higher gypsum content, less compressive strength was achieved. The reduction was drastic for high replacement ratios of GGBFS (S60 and S80 mixtures).
Therefore, it is not recommended to use high ratios of GGBFS in CAC

containing SCM mixtures. F20 and S20 showed similar behavior at early ages. At CAC-silica fume combinations, the decrease in compressive strength results was lower as compared to other supplementary binder combinations. On the other hand, Benli (36) conducted that fly ash and silica fume addition reached up compressive and flexural strengths of SCMs at 180 days. From the hardened state results of all CAC containing SCM mixtures, it is seen that addition of silica fume in the SCM had beneficial effects on the hardened properties. Additionally, for the CAC-GGBFS containing SCM mixtures, the replacement ratio should be determined precisely, as the higher contents of GGBFS caused negative effects on the strength and abrasion resistance. Unlikely, a study (37) evaluated the development of strength by the replacement of GGBFS up to $60 \%$ did not show strength reduction at later ages. In the sense of flexural and compressive strengths and abrasion resistance test results it can be said that satisfied outcomes obtained from them can be the sign of better durability and stability for SCMs.

\section{Conclusion}

In this paper, self-compacting mortar mixtures were produced by using CAC. For this purpose, 11 different mixtures were prepared, and their fresh and hardened state properties were determined. According to investigations and performed tests in this study the following conclusions can be summarized:

1. It can be claimed that self-compacting mortars were successfully produced with CAC and supplementary binders used in this study according to the fresh state properties. 
2. The aimed fresh state properties were achieved by adjusting the superplasticizer content and supplementary binder ratio.

3. Replacement of CAC by gypsum decreased the setting time while, replacement of CAC by GGBFS increase the setting time. The effect of silica fume on setting time was dependent on the replacement ratio.

4. In the manner of abrasion resistance, all SCM samples except S80, showed small thickness reductions at all ages.

5. In terms of flexural strength results of CAC including mortars, C, SF10, S40 and S60 showed strength gain in time.

6. In the manner of compressive strength results of SCM mixtures, SF5, SF10, and S40 did not exhibit strength reduction during the time.

7. Based on fresh and hardened states properties it was clearly seen that blending CAC with silica fume for SCM production was beneficial in terms of strength loss compensation, abrasion resistance capacity, and flowability.

\section{Acknowledgements}

This study has been partially granted (Project Grand Number: BAP 17/081) by Muğla Sitkı Koçman University Research Projects Coordination Office. The authors also acknowledge ÇİMSA Mersin Cement Factory, BASF Chemical Company and Yatağan Thermal Power Plant for their material support.

\section{References}

[1] Nunes, S. and Costa, C., "Numerical Optimization of self-compacting mortar mixture containing spent equilibrium catalyst from oil refinery", Journal of Cleaner Production, 158: 109-121, 2017.

[2] Tuaum, A., Shiote, S.M. and Oyaawa, W., "Experimental study of self-compacting mortar incorporating recycled glass aggregate", Buildings, 8(2): 1-15, 2018.

[3] Navarro-Blasco, I., Fernandez, J.M., Duran A., Sirera, R. and Alvarez, J.I., "A novel use of calcium aluminate cements for recycling waste foundry sand (WFS)", Construction and Building Materials, 48: 218-228, 2013.

[4] Garces, P., Zornoza, E., Alcocel, E.G., Galao, O. and Andion, L.G., "Mechanical properties and corrosion of CAC mortars with carbon fibers", Construction and Building Materials, 34: 91-96, 2012.

[5] Maaroufi, M., Lecomte, A., Diliberto, C., Francy, 0. and Le Brun, P., "Thermo-hydrous behavior of hardened cement paste based on calcium aluminate cement", Journal of the European Ceramic Society, 35: 1637-1646, 2014.
[6] Luz, A.P. and Pandolfelli, V.C., "Halting the calcium aluminate cement hydration process", Ceramics International, 37: 3789-3793, 2011.

[7] Silva, A.P., Segades, A.M., Pinto, D.G., Oliveira, L.A. and Devezas, T.C., "Effect of particle size distribution and calcium aluminate cement on the rheological behaviour of all-alumina refractory castables", Powder Technology, 226: 107-113, 2012.

[8] Antonovic, V., Keriene, J., Boris R. and Aleknevicius M., "The Effect of Temperature on the Formation of the Hydrated Calcium Aluminate Cement Structure", Procedia Engineering, 57: 99-106, 2013.

[9] Damidot, D. and Rettel, A., "Effect of Gypsum on $\mathrm{CA}$ and $\mathrm{C}_{12} \mathrm{~A}_{7}$ Hydration at Room Temperature", $11^{\text {th }}$ International Congress on the Chemistry of Cement, 2003, 0-9584085-8-0.

[10] Fernandez-Carrasco, L. and Vazquez, E., "Reactions of fly ash with calcium aluminate cement and calcium sulphate", Fuel, 88: 15331538, 2009.

[11] Lopez, A.H., Calvo, J.L.G., Olmo, J.G., Petit, S. and Alonso, M.C., "Microstructural Evolution of Calcium Aluminate Cements Hydration with Silica Fume and Fly Ash Additions by Scanning Electron Microscopy, and Mid and Near-Infrared Spectroscopy", The American Ceramic Society, 91 [4] 1258-1265, 2008.

[12] Parr, C., Bin, L., Alt, C. and Wohrmeyer, C., "Interactions between silica fume and cac and methods to optimize castable placing properties", Refractories Applications and News, 1: 12-18, 2007.

[13] Tanzer, R., Buchwald, A. and Stephan, D., "Effect of slag chemistry on the hydration of alkaliactivated blast-furnace slag", Materials and Structures, 48: 629-641, 2015.

[14] Kırca, Ö., Yaman İ.Ö. and Tokyay M., "Compressive Strength Development of Calcium Aluminate Cement-GGBFS Blends", Cement and Concrete Composites, 35: 163-170, 2013.

[15] Bizzozero, J. and Scrivener, K.L., "Limestone reaction in calcium aluminate cemen-calcium sulfate systems", Cement \& Concrete Research, 76: 159-169, 2015.

[16] Samad, S. and Shah, A., "Role of binary cement including Supplementary Cementitious Material (SCM), in production of environmentally sustainable concrete: A critical review, International Journal of Sustainable Built Environment, 6, 663-674, 2017.

[17] Mostafa, N.Y., Zaki, Z.I. and Elkader, O.H.A., "Chemical activation of calcium aluminate cement composites cured at elevated temperature", Cement \& Concrete Composites, 34: 1187-1193, 2012.

[18] Felekoğlu B., Tosun K., Baradan B., Altun A., and Uyulgan B., "The effect of fly ash and limestone 
fillers on the viscosity and compressive strength of self-compacting repair mortars", Cement and Concrete Research, 36: 1719-1726, 2006.

[19] Madduru, S.R.C., Pallapothu, S.N.R.G., Pancharathi, R.K., Garje, R.K. and Chakilam, R., "Effect of self-curing chemicals in selfcompacting mortars", Construction and Building Materials, 107: 356-364, 2016.

[20] Şahmaran, M., Christianto, H.A. and Yaman, İ.Ö., "The effect of chemical admixture and mineral additives on the properties of self-compacting mortars", Cement \& Concrete Composites, 28: 432-440, 2006.

[21] Gowda, M.R. and Abhilash, D.T., "Development of self-compacting mortar mixes using agor based waste as a partial replacement to cement", Indian Concrete Journal, 91(4): 87-92, 2017.

[22] Türedi, G., Production of Self-compacting Mortar with Calcium Aluminate Cement, M Sc Thesis, Muğla Sitkı Koçman University, Muğla, 2019.

[23] Turk, K., "Viscosity and hardened properties of self-compacting mortars with binary and ternary cementitious blends of fly ash and silica fume", Construction and Building Materials, 37: 326334, 2012.

[24] ASTM C143 / C143M-15, Standard Test Method for Slump of Hydraulic-Cement Concrete, Annual Book of ASTM Standards, Vol. 04.02, 2015.

[25] EFNARC, Specification and guidelines for selfcompacting concrete. European Federation for Specialist Construction Chemicals and Concrete Systems, Norfolk, UK, English ed., February 2002.

[26] ASTM C807 - 18, Standard Test Method for Time of Setting of Hydraulic Cement Mortar by Modified Vicat Needle, Annual Book of ASTM Standards, Vol. 04.01, 2018.

[27] Benabed, B., Kadri, E., Azzouz, L. and Kenai, S., "Properties of self-compacting mortar made with various types of sand", Cement \& Concrete Composites, 34(10): 1167-1173, 2012.

[28] ASTM C944 - 99, Standard Test Method for Abrasion Resistance of Concrete or Mortar Surfaces by the Rotating-Cutter Method, Annual Book of ASTM Standards, Vol.04.02, 2012.

[29] TS EN 196-1:2016, Methods of testing cement- Part 1: Determination of strength, Turkish Standards Institution, May 2016.

[30] Benli, A. and Karataș, M., "Uçucu kül ve silis dumanı ikameli karıșımlardan üretilen kendiliğinden yerleşen harçların durabilite ve dayanım özellikleri", DÜMF Mühendislik Dergisi, 10: 1 (2019): 335-345.

[31] Kırca, Ö., Temperature Effect of Calcium Aluminate Cement Based Composite Binders, $\mathrm{PhD}$ Thesis, Middle East Technical University, Ankara, 2006

[32] Güneyisi, E. and Gesoğlu, M., "Properties of selfcompacting mortars with binary and ternary cementitious blends of fly ash and metakaolin", Materials and Structure, 41: 1519-1531, 2008.

[33] Turk, K. and Karatas, M., "Abrasion Resistance and Mechanical Properties of Self-Compacting Concrete with Different Dosages of Fly Ash/Silica Fume, Indian Journal of Engineering and Materials Sciences, Vol. 18, February 2011.

[34] Khaliq, W. and Khan, H.A., "High temperature material properties of calcium aluminate cement concrete", Construction and Building Materials, 94: 475-487, 2015.

[35] Courard, L., Michel, F. and Pierard, J., "Influence of clay in limestone fillers for self-compacting cement-based composites", Construction and Building Materials, 25: 1356-1361, 2011.

[36] Benli, A., "Mechanical and durability properties of self-compacting mortars containing binary and ternary mixes of fly ash and silica fume", Structural Concrete, pp: 1096-1108, 2019.

[37] Yang, H.J., Ann, K.Y. and Jung, M.S., "Development of Strength for Calcium Aluminate Cement Mortars Blended with GGBS", Advances in Materials Science and Engineering, Volume 2019, Article ID 9896012. 